\title{
A rokkantság, megváltozott munkaképesség, rehabilitációs ellátások változása Magyarországon 1990 és 2015 között
}

\author{
Kovács Gábor dr. \\ Széchenyi István Egyetem, Egészség- és Sporttudományi Kar, Győr
}

\begin{abstract}
Bevezetés: A megváltozott munkaképességú személyek részére kifizetett és jelenleg az Egészségbiztosítási Alap költségvetésének közel $30 \%$-át kitevő pénzbeli ellátásokra való jogosultság megállapítása, a keret racionális felhasználása régóta komoly problémákat vet fel.

Célkitüzés: A tanulmány célja az elmúlt 25 év statisztikai adatainak és a jogszabályi környezet változásának az összehasonlító vizsgálata.

Módszerek: Vizsgálatainkat az Országos Egészségbiztosítási Pénztár, a Központi Statisztikai Hivatal adatsoraira, valamint az Állami Számvevőszék, továbbá a Nemzetgazdasági Minisztérium államháztartási jelentéseire alapoztuk. A vizsgált időszakra vonatkozóan elemeztük a megváltozott munkaképességú személyek számára kifizetett pénzbeli ellátások mértékét, az azok csökkentésére tett intézkedéseket, illetve az alapul fekvő jogszabályi háttér változását. Hosszmetszetben vizsgáltuk a háttérben húzódó komplex társadalmi, szociológiai folyamatainak vonatkozó dimenziót, továbbá a megváltozott munkaképesség orvosszakmai értékelésének rendszerét, illetve a komplex rehabilitációs ellátások megjelenését, hatásait.

Eredmények: Az elmúlt 25 évben az eltérô megnevezés alatt (rokkantság, munkaképesség-csökkenés, egészségkárosodás, rehabilitációs ellátás) kifizetett pénzbeli ellátások (járadék, nyugellátás) az Egészségbiztosítási Alap költségvetésének még ma is meghatározó részét képezik (2016-ban 315 milliárd forint). Komoly erőfeszítések történtek arra, hogy a régebben alapvetóen automatikusan folyósított rokkantsági nyugdíj és járadék rendszerét a megmaradt egészségi állapotra építő, azt megtartó, javító komplex orvosi, foglalkozási és szociális rehabilitációval váltsák fel. Az intézkedések célja alapvető́n a költségvetés kiadásainak csökkentése, illetve a kifizetett összeg rehabilitációs ellátásokra építő eredményesebb hasznosulása.

Következtetés: A vizsgált hosszú idôperiódusban lezajló társadalmi, szociológiai változások sajnálatosan elősegítették a rokkantsági ellátást igénybe vevők számának kezdetben gyors emelkedését, majd magas szinten stabilizálódását és a költségvetés jelentős terhelését. Ezt a pénzbeni ellátás rehabilitációs szemléletủ átalakítása sem volt képes kellóen ellensúlyozni.
\end{abstract}

Orv Hetil. 2019; 160(Suppl 1): 29-36.

Kulcsszavak: rokkantság, rehabilitációs ellátás, megváltozott munkaképesség, egészségkárosodás

\section{Changes in disability, reduced working ability and rehabilitation benefits in Hungary between 1990 and 2015}

Introduction: In our study, based on the data of the last 25 years, we analyzed the changes in the cash benefits paid to people with reduced working capacity, currently accounting for nearly $30 \%$ of the budget of the National Health Insurance Fund of Hungary.

Aim: The purpose of our study is to compare the statistical data of the past 25 years and the changes in the legal environment.

Methods: Our research was based on the data series of the National Health Insurance Fund of Hungary and the Hungarian Central Statistical Office as well as on the public finance reports of the State Audit Office of Hungary and the Ministry for National Economy. For the period under review, we analyzed the extent of the cash benefits paid to people with reduced working capacity, the measures taken to reduce these benefits, and the related legal background. In the long term, we examined the relevant dimension of the complex sociological processes in the background as well as the medical evaluation of the changed working ability. 
Results: In the last 25 years, benefits (annuity, retirement) paid under different denominations (disability, work ability reduction, health impairment, rehabilitation benefit) are still a decisive part of the health insurance budget (HUF 315 billion in 2016). Serious efforts have been made to replace the previously funded system of invalidity pension and annuity system, with the complex medical, occupational, and social rehabilitation, maintenance and improvement of the remaining state of health. The purpose of the measures is essentially to reduce budget expenditures and to improve the utilization of the amount paid on rehabilitation benefits.

Conclusion: The sociological changes that occurred during the long period of time regrettably helped to initially increase the number of recipients of invalidity benefits, to stabilize them at a high level and to have a significant burden on the budget. This could not be counterbalanced by the rehabilitation approach of money supply either.

Keywords: disability, rehabilitation benefit, impaired working ability, health impairment

Kovács G. [Changes in disability, reduced working ability and rehabilitation benefits in Hungary between 1990 and 2015]. Orv Hetil. 2019; 160(Suppl 1): 29-36.

\section{Rövidítések}

E. Alap = Egészségbiztosítási Alap; KSH = Központi Statisztikai Hivatal; NEAK = Nemzeti Egészségbiztosítási Alapkezelő (korábbi nevén OEP); NEFMI = Nemzeti Erőforrás Minisztérium; NGM = Nemzetgazdasági Minisztérium; NRSZH = Nemzeti Rehabilitációs és Szociális Hivatal; NYA = Nyugdíjbiztosítási Alap; OEP = Országos Egészségbiztosítási Pénztár

A második világháborút követően csak 1950 körül kezdődött, és végül 1958-ra szilárdult meg egy egységes felosztó-kirovó nyugdíjrendszer kiépítése [1], amely akkor a népesség 47\%-át érte el [2]; a későbbiek során azonban a jogosultságot és a járadékok körét fokozatosan kiterjesztették, így 1975-re a rendszer teljessé vált [3]: közel 100\%-os aránnyal és átfogó időskori, hozzátartozói és rokkantsági nyugdíjjárulék-elemekkel rendelkezett [4]. A megváltozott munkaképességú személyek pénzbeli ellátása kezdetben a nyugdíjrendszer keretein belül körvonalazódott [5]. 1992-ben létrejött az állami költségvetéstől független Nyugdíjbiztosítási Alap (NYA), saját igazgatással, önálló költségvetéssel.

Ezzel egy időben hozták létre az Egészségbiztosítási Alapot (E. Alap), amelyból elsősorban a természetbeni egészségügyi ellátást és a táppénzt finanszírozták. A rokkantak és hozzátartozóik pénzbeli ellátása megoszlott a két alap között: az E. Alap fizette a nyugdíjkorhatár alatti rokkantak járadékát és haláluk esetén a hozzátartozói járadékokat. A nyugdijkorhatár feletti rokkantak nyugdíját azonban a NYA fizette. A rokkantsági ellátásban részesülők száma 1968-tól folyamatos emelkedést mutatott, és már korán a szociális ellátáshoz kezdett hasonlítani. (1968-ban 20406 fó részesült rokkantsági ellátásban, ami ezer dolgozóra 46 föt jelentett, míg 1989-ben már 70518 fó, ami ezer dolgozóra vetítve 112 fót jelentett) [6] (1. táblázat). A növekedés üteme a rendszerváltást követően felgyorsult, a rokkantsági igényt bejelentők és a rokkantsági ellátásban részesülők száma ugrásszerúen megnövekedett.

Ekkor a gyors társadalmi és gazdasági átalakulás nyomán kialakuló munkanélküliségben a hiányzó szociális intézményrendszer szerepét vette át [7]. A rendszerváltást követő időszakban egyre nagyobb jelentőségük lett a
1. táblázat | Az új rokkantsági nyugdíjasok száma (fó, 1968-1989)

\begin{tabular}{|c|c|c|c|c|}
\hline \multirow[t]{3}{*}{ Év } & \multicolumn{4}{|c|}{ Az új rokkantsági nyugdíjasok száma } \\
\hline & \multicolumn{2}{|c|}{ Munkás és alkalmazott } & \multicolumn{2}{|c|}{$\begin{array}{l}\text { Mezőgazdasági } \\
\text { szövetkezeti tag }\end{array}$} \\
\hline & száma, fó & $\begin{array}{c}\text { ezer munkásra } \\
\text { és alkalma- } \\
\text { zottra jutó } \\
\text { száma }\end{array}$ & száma, fő & $\begin{array}{c}\text { ezer munkásra } \\
\text { és alkalma- } \\
\text { zottra jutó } \\
\text { száma }\end{array}$ \\
\hline 1968 & 16257 & 46,0 & 4149 & 60,7 \\
\hline 1969 & 16765 & 46,5 & 6729 & 99,5 \\
\hline 1970 & 18571 & 49,1 & 11576 & 175,3 \\
\hline 1971 & 22537 & 58,5 & 14963 & 239,5 \\
\hline 1972 & 25490 & 65,5 & 13452 & 225,4 \\
\hline 1973 & 24312 & 61,5 & 13950 & 242,9 \\
\hline 1974 & 22857 & 57,0 & 12764 & 231,9 \\
\hline 1975 & 24022 & 59,2 & 10075 & 180,0 \\
\hline 1976 & 27232 & 66,8 & 8157 & 150,9 \\
\hline 1977 & 27551 & 67,4 & 7172 & 133,6 \\
\hline 1978 & 25879 & 62,8 & 6108 & 114,4 \\
\hline 1979 & 27158 & 65,9 & 5618 & 105,4 \\
\hline 1980 & 29187 & 71,6 & 5122 & 97,5 \\
\hline 1981 & 29389 & 72,4 & 5151 & 99,6 \\
\hline 1982 & 29751 & 73,4 & 5132 & 100,2 \\
\hline 1983 & 29531 & 72,9 & 5089 & 101,8 \\
\hline 1984 & 30875 & 76,4 & 5705 & 117,9 \\
\hline 1985 & 31904 & 79,4 & 6009 & 130,6 \\
\hline 1986 & 31610 & 78,9 & 5359 & 124,6 \\
\hline 1987 & 34748 & 87,0 & 5663 & 134,8 \\
\hline 1988 & 37178 & 93,7 & 6213 & 156,4 \\
\hline 1989 & 43974 & 112,0 & 6138 & 164,1 \\
\hline
\end{tabular}

Forrás: az Országos Társadalombiztosítási Főigazgatóság statisztikai jelentése, 1990

forrásallokációs kérdéseknek a nagy társadalmi elosztórendszerekben, így az egészségügyi és szociális szektorban is [8-13]. A két forráshiányos terület esetében az ellátandó feladatok ilyen jellegü keveredése nem erősítet- 
Ezer fö

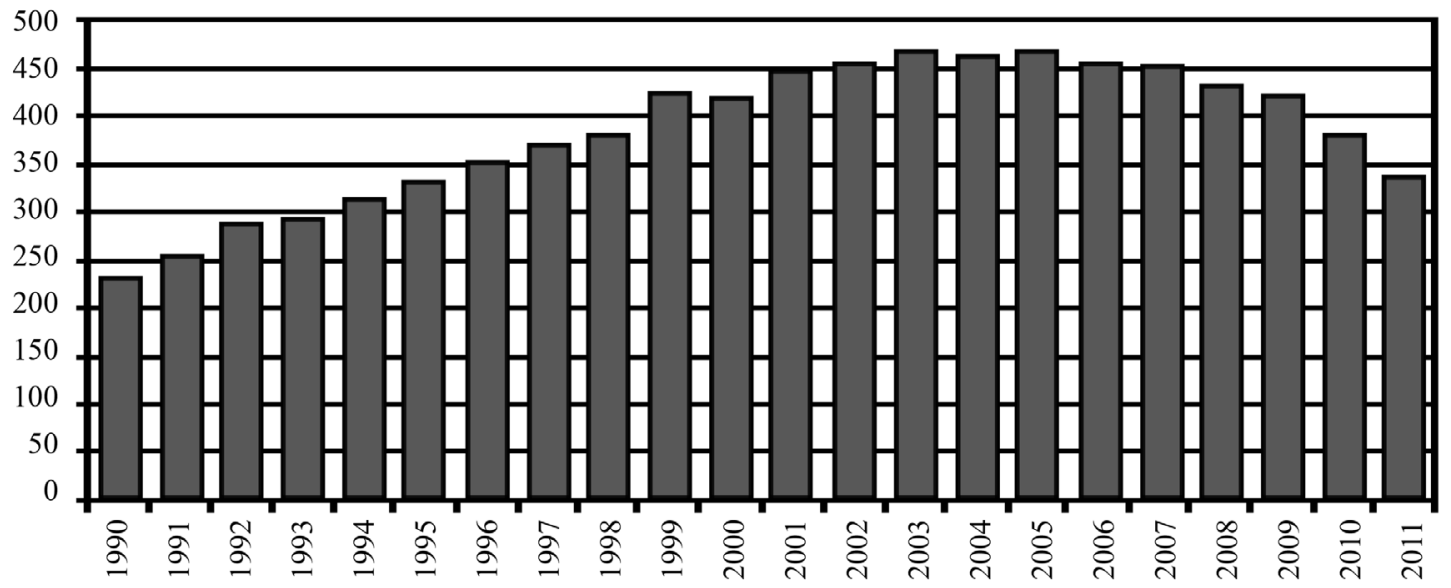

1. ábra

\footnotetext{
| A rokkantsági nyugdíjban részesülők számának alakulása (1990-2011)

Forrás: Központi Statisztikai Hivatal
}

te sem a szakmai múködést, sem a gazdálkodást [1418 .

A rendszerváltást megelőzően és azt követően is valamennyi kormány megpróbálta kezelni a problémát, ami valójában kevés eredménnyel járt, hiszen a KSH jelentése szerint [19] 2001-ben Magyarországon megközelítően már 800 ezer rokkantnyugdíjas volt, közülük 447 ezer korhatár alatti (262 ezer férfi, 185 ezer nő) [19]. A statisztikai adatok alapján megállapítható, hogy a bevezetett intézkedések hatására csak 2008-ban torpant meg az emelkedés, és az értékelhető mértékü csökkenés 2010 ben volt detektálható először; 2011-ben a korhatár alatti rokkantnyugdíjasok száma 337 ezer före csökkent [20] (1. ábra). Az elmúlt 25 évben az eltérő megnevezés alatt (rokkantság, munkaképesség-csökkenés, egészségkárosodás, rehabilitációs ellátás) kifizetett pénzbeli ellátások (járadék, nyugellátás) az E. Alap költségvetésének ma is meghatározó részét képezik (2016-ban 323 milliárd forint); arányukat tekintve megállapítható, hogy az E. Alap teljes költségvetésének $28,7 \%$-a pénzbeli ellátás, melynek több mint felét, 52,6\%-át tették ki a rokkantsággal és a rehabilitációval kapcsolatos kiadások. Összehasonlításként jegyezzük meg, hogy ugyanekkor éves szinten a gyógyszerár-támogatás 305 milliárd, a gyógyászati segédeszközök támogatása 55 milliárd, illetve a mentésre fordított összeg 29 milliárd forintot tett ki [21]. A korábbiakból következik, hogy a nyugdíjkorhatár előtti rokkantsági ellátás kérdése komplex értékelést igényel, hiszen az ellátást igénylők számának alakulását egészségügyi, gazdasági, társadalmi tényezők is befolyásolják. A magyar lakosság egészségi állapotának kedvezőtlen volta, az ebből adódó egészségügyi, finanszírozási, keresőképtelenségi problémák jelentős társadalmi terhet okoznak [22-26].

Tanulmányunkban az elmúlt 25 év adatait és a jogszabályi környezetet együttesen vizsgálva a megváltozott munkaképességű személyek részére kifizetett és jelenleg az E. Alap költségvetésének közel 30\%-át kitevő pénzbeli ellátásokat terhelő részét, és annak változásait tekintjük át. A vizsgált időszakban komoly erőfeszítések történtek arra, hogy a régebben alapvetően automatikusan folyósított rokkantsági nyugdíj és járadék rendszerét a megmaradt egészségi állapotra építő, azt megtartó, javító komplex orvosi, foglalkozási és szociális rehabilitációval váltsák fel. Az intézkedések célja alapvetően a költségvetés kiadásainak csökkentése, illetve a kifizetett összeg rehabilitációs ellátásokra építő eredményesebb hasznosulása.

\section{Adatok és módszerek}

Elemzésünket a Nemzeti Egészségbiztosítási Alapkezelő (NEAK), korábbi nevén az Országos Egészségbiztosítási Pénztár (OEP), a Központi Statisztikai Hivatal adatsoraira, valamint az Állami Számvevőszék és a Nemzetgazdasági Minisztérium államháztartási jelentéseire alapoztuk. A vizsgált időszakra vonatkozóan elemeztük a megváltozott munkaképességű személyek számára kifizetett pénzbeli ellátások mértékét, az azok csökkentése érdekében hozott jogszabályi és intézményi változásokat. A jogszabályok vizsgálatát hosszmetszeti jog-összehasonlitó módszertannal végeztük el, ennek keretében a jogszabálymódosítások tartalmát, célját, várt hatását vizsgáltuk. Hosszmetszetben vizsgáltuk a háttérben húzódó komplex társadalmi, szociológiai folyamatok vonatkozó dimenziót, továbbá a megváltozott munkaképesség orvosszakmai értékelésének rendszerét, jogszabályi hátterét, illetve a komplex rehabilitációs ellátások megjelenését, hatásait. Elemzésünk időtávja az 1968 és 2016 közötti időszakra terjed ki.

Feldolgoztuk az 1968-tól 1989-ig terjedő időszak statisztikai adatait, vizsgáltuk az új rokkantsági nyugdíjasok számát és azok ezer foglalkoztatottra jutó számát is. Ele- 


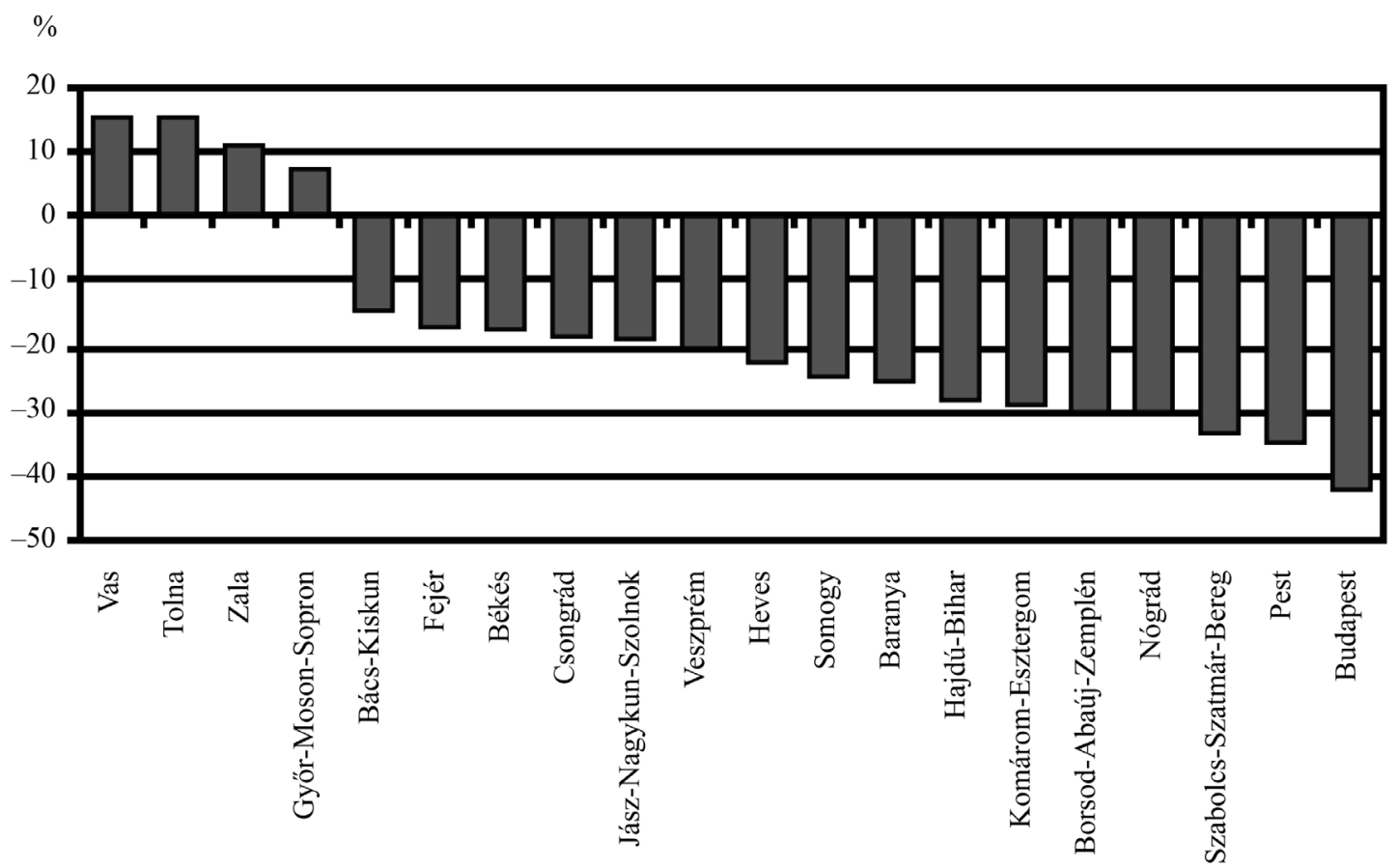

2. ábra $\quad$ A korhatár alatti rokkantsági nyugdíjasok számának változása megyénként a 2001 és 2011 közötti tízéves időszakban Forrás: Központi Statisztikai Hivatal

meztük az 1990-2011-es időszakban a rokkantsági nyugdíjban részesülők számát. Ezen belül éves bontásban elemeztük az új nyugdíj-megállapítások számát, a rokkantsági és baleseti rokkantsági nyugdíjak megállapításának számát, illetve a 2008. évtől belépő rehabilitációsjáradék-megállapítások számát. Az adatsort összevetettük a 2008. évtől bevezetett jogszabály-módosításokkal és intézményátalakítási csomaggal (2. ábra és 2. táblázat).

A következő lépcsőben a 2012-ben bevezetett jogszabályváltozások hatását vizsgáltuk (3. táblázat). Az újonnan bevezetésre került nyugdij-megállapításokon belül elemeztük az életkor, illetve a szolgálati idő betöltésével keletkező jogosultságot, valamint az újonnan megállapított rokkantsági és rehabilitációs ellátásban részesülők számát. Ezen belül vizsgáltuk a 2012-től érvénybe lépő új orvosszakmai minősítési rendszer hatását is [27]. Vizsgáltuk a rokkantsági nyugdíjban részesülők területi megoszlását is (2. ábra).

\section{Eredmények}

A jogszabályelemzés és jog-összehasonlítás alapján megállapítható, hogy a kötelező egészségbiztosítási ellátásról szóló 1997. évi LXXXIII. törvénnyel beiktatott és 1998tól hatályba lépett joganyag érdemben nem érintette sem a munkaképesség-csökkenés megítélésének szempontrendszerét, sem pedig a rokkantsági ellátás igénybevételének egyéb feltételeit. Kedvező változás a rehabilitációs járadékról szóló 2007. évi LXXXIV. törvény hatálybalé- pésétől kezdve volt remélhető - témánk szempontjából tehát ez tekinthető az első érdemi és megközelítésében újszerü koncepciónak. A törvény preambuluma szerint az Országgyúlés az egészségkárosodást szenvedett személyek megmaradt, fejleszthetô képességeire épülö rehabili-

2. táblázat |A rokkantsági nyugdíjban részesülők számának alakulása (19902011)

\begin{tabular}{|c|c|c|c|c|c|}
\hline \multirow{2}{*}{ Év } & \multirow{2}{*}{$\begin{array}{c}\text { Az új } \\
\text { nyugdíj- } \\
\text { megállapí- } \\
\text { tások } \\
\text { száma }\end{array}$} & \multicolumn{4}{|c|}{ Ebből: saját jogú } \\
\hline & & öregségi & $\begin{array}{l}\text { rokkant- } \\
\text { sági és } \\
\text { baleseti } \\
\text { rokkantsági }\end{array}$ & $\begin{array}{l}\text { rehabilitá- } \\
\text { ciós } \\
\text { járadék }\end{array}$ & $\begin{array}{l}\text { foglalkoz- } \\
\text { tatáspoliti- } \\
\text { kai okból }\end{array}$ \\
\hline 2000 & 168669 & 41577 & 54196 & - & 3574 \\
\hline 2001 & 170513 & 43165 & 58765 & - & 3997 \\
\hline 2002 & 174416 & 51427 & 53214 & - & 3477 \\
\hline 2003 & 173334 & 47239 & 52062 & - & 4366 \\
\hline 2004 & 180296 & 65886 & 45966 & - & 4120 \\
\hline 2005 & 192784 & 77425 & 42877 & - & 3830 \\
\hline 2006 & 182452 & 78923 & 39211 & - & 3300 \\
\hline 2007 & 202926 & 98553 & 34386 & - & 8210 \\
\hline 2008 & 168168 & 70073 & 26272 & 2246 & 9712 \\
\hline 2009 & 155794 & 48989 & 23238 & 12525 & 8735 \\
\hline 2010 & 152229 & 43703 & 24994 & 13210 & 9152 \\
\hline 2011 & 203044 & 107323 & 22097 & 8532 & 7480 \\
\hline
\end{tabular}

Forrás: Központi Statisztikai Hivatal 
tációjának, társadalmi reintegrációjának elősegítésére, továbbá a rehabilitáció időtartamára a jövedelemarányos keresetpótlás érdekében alkotta a törvényt. A joganyag a munkaképesség-csökkenés felváltására bevezette az egészségkárosodás fogalmát [28], és elsőként belyezte a bangsúlyt a rehabilitációra, amelynek törvény szerinti célja az egészségkárosodást szenvedett személy szakmai munkaképességének biztosítása, amely a külön jogszabályban meghatározott orvosi, foglalkoztatási, szociális, képzési és egyéb tevékenységek komplex rendszereként valósul meg. A törvény felhatalmazása alapján, erre alapozva született meg a 213/2007. (VIII. 7.) Korm. rendelet az Országos Rehabilitációs és Szociális Szakértői Intézetről, valamint a bizottságok eljárásának részletes szabályairól. A rendelet 2008. január 1 -jétől bevezette a rehabilitációs járadékot és a megváltozott munkaképességűek komplex minősítését. A rendelet alapján jött létre a megváltozott munkaképességü személyek egészségkárosodásának elbírálására hivatott Országos Rehabilitációs és Szociális Szakértői Intézet, továbbá rögzítette az egészségkárosodás véleményezésének szempontrendszerét, megállapításának szabályait, a 24 és 36 hónap időtartamú komplex orvosi, szociális, foglalkozási rehabilitáció fogalmát, célját, alapelveit. A minősítés a megmaradt egészségi állapotra, a fejleszthető képességek feltárására és a rehabilitációs esélyek értékelésére helyezte a hangsúlyt. Valamennyi, rokkantsági nyugdíjban részesülő személy - már az új szempontok szerinti - tervszerü, ütemezett felülvizsgálatát vezette be. Az új koncepció vegyes eredményeket hozott, mivel kétségtelenül jelentősen csökkent az új igénybejelentések száma, és kismértékben csökkent a rokkantsági ellátásban részesülők köre is. Az új igénybejelentések száma 2007-ben 98553 fó, 2008-ban 70073 fó, 2009-ben 48989 fó volt, azonban 2010-ben a folyamat megfordult, és 2011-ben már ismét 107323 új rokkantsági igénybejelentés történt (2. táblázat). A számadatok azt jelzik, hogy a rehabilitációs ellátásra utaltak a 36 havi rehabilitációs ellátás leteltével ismét rokkantsági igénylőként jelentek meg. Ez valójában a rehabilitáció kisebb sikerét jelzi, hiszen a 2008 és 2010 közötti három évben összesen 74504 rehabilitációs igénybejelentés történt, azonban a 2010. évihez képest 2011-ben 63620 fóvel növekedett meg az új rokkantsági igénybejelentők száma, azaz csaknem annyival, mint ahány foót korábban rehabilitációs útra tereltek. Az Országos Rehabilitációs és Szociális Szakértői Intézetet 2010-ben megszüntették, és a 331/2010. (XII. 27.) Korm. rendelet új szervezeti egységet - a Nemzeti Rehabilitációs és Szociális Hivatalt (NRSZH) - hívott életre, valamint meghatározta annak részben új eljárási szabályait. Valódi szemléletváltozást ugyanakkor csak a 7/2012. (II. 14.) NEFMI rendelet jelentett, amely az egészségkárosodás mellett a megmaradt egészségi állapotot értékeli, és a korábbinál egységesebb, könnyebben alkalmazható szabályokkal homogénebbé tehette az orvosszakértői véleményezést. Az NRSZH adatsora szerint [29] a 2011. évben 845913 fó részesült rokkantsági, baleseti rokkantsági nyugdíjban, átmeneti járadékban, rendszeres szociális segélyben, míg az új orvosszakmai, illetve komplex értékelési szempontrendszer bevezetését követő két évvel később, a 2015. évben 385819 fö, ez pedig jelentős összlétszámcsökkenést igazol. A KSH vonatkozó statisztikai adatsoraiban [18] ugyanakkor azt látjuk, hogy az új rokkantsági ellátások száma 2012 és 2016 között ennek ellenére fokozatosan növekedett (3. táblázat) (2012: 44486 fó, 2013: 65512 fo', 2014: 53128 fó, 2015: 82424 fó, 2016: 94997 fó). Erre figyelemmel nagy fokban valószínúsíthető, hogy a minősítési rendszer további fejlesztése, finomítása vagy akár egyszerúsítése további orvosszakmai, szakértői eredményt nem tartogat. Az Állami Számvevőszék Kutató Intézete a megváltozott munkaképességű személyek támogatási rendszerét, valamint társadalmi-gazdaságossági hatékonyságát átfogóan vizsgálta. Megállapította, hogy „a foglalkozási rehabilitáció kiemelt kezelése is viszonylagossá vált. A képzés és átképzés, amely elvileg a foglalkozási rehabilitáció legfontosabb eszköze, 2008-ra marginálissá vált" [30]. Hazánkban az 1990-es évek második felétől kezdve a foglalkozási rehabilitáció prioritást kapott a munkaügyi központok tevékenységében. Minden megyében foglalkozási rehabilitációs munkacsoport, majd Rehabilitációs Információs Centrum alakult. A jogszabályelemzés alapján is megállapítható, hogy bár 2007ben megszületett a megváltozott munkaképességúek

3. táblázat |A rokkantsági nyugdíjban részesülők számának alakulása (2012-2016)

\begin{tabular}{|c|c|c|c|c|c|c|}
\hline \multicolumn{7}{|c|}{ Új nyugdíj-megállapítások a nyugellátás iránti igényt teljesítő határozatok alapján (2012-2016) } \\
\hline \multirow[t]{2}{*}{ Év } & \multirow{2}{*}{$\begin{array}{l}\text { Új megállapítások } \\
\text { száma }\end{array}$} & \multicolumn{5}{|c|}{ Ebből: } \\
\hline & & öregségi nyugdíj & $\begin{array}{l}\text { nôknek } 40 \text { év } \\
\text { jogosultsági idő } \\
\text { alapján járó nyugdijj }\end{array}$ & $\begin{array}{c}\text { életkoron alapuló } \\
\text { ellátások }\end{array}$ & rokkantsági ellátások & $\begin{array}{c}\text { rehabilitációs } \\
\text { ellátások }\end{array}$ \\
\hline 2012 & 212815 & 77471 & 29375 & 6442 & 44486 & 19541 \\
\hline 2013 & 220635 & 60784 & 25118 & 7487 & 65512 & 28078 \\
\hline 2014 & 181106 & 54130 & 27218 & 1492 & 53128 & 16308 \\
\hline 2015 & 231787 & 68656 & 28050 & 1939 & 82424 & 20140 \\
\hline 2016 & 265395 & 95483 & 29739 & 2252 & 94997 & 14387 \\
\hline
\end{tabular}

Forrás: Központi Statisztikai Hivatal 
komplex értékelésének új orvosszakmai szabályrendszere, ugyanakkor a komplex rehabilitáció (orvosi, szociális, foglalkozási) tervszerü, koordinált és az egyén szükségleteihez igazított folyamata nem alakult ki teljességében. A komplex rehabilitációs modell eredményeinek és hibáinak folyamatos értékelése és a rendszer fejlesztése lett volna indokolt. A jelentés megállapítása szerint a komplex rehabilitációs rendszer kialakításának egyik kulcskérdése az orvosi rehabilitáció fejlesztése [31-35]. A komplex rehabilitáció folyamatának egyik gyenge pontja tehát az, hogy a rehabilitáció koordinálásáért felelős munkaügyi szervek nem tudták befolyásolni az orvosi rehabilitáció folyamatát, holott az eredményes orvosi rehabilitáció a foglalkozási rehabilitáció tényleges megkezdésének előfeltétele. A tanulmány a Rehabilitációs Szakmai Kollégium javaslata alapján amellett érvel, hogy az orvosi rehabilitációban a valódi progresszivitást megvalósító háromszintű (rehabilitációs alap-, regionális és speciális ellátás országos szinten) ellátásra lenne szükség. Megállapítható az is, hogy a rehabilitáció minden területe szakemberigényes, ugyanakkor valamennyi szegmensben szakemberhiány van. A jogi szabályozás alapján meghatározható a rehabilitáció lehetséges és konkrét iránya. A rehabilitáció lehetséges irányait az érintett személy egészségkárosodásának, szakmai munkaképessége megváltozásának (foglalkozási rehabilitáció), valamint a rehabilitációt segítő szolgáltatások rendelkezésre állásának alapján kell megállapítani. A rehabilitáció lehetséges irányaként az egészségkárosodás jellegétől és súlyosságától függően több foglalkozás és foglalkozási alcsoport megjelölésére is sor kerülhet. A foglalkozási rehabilitáció rendszerint csak azt követően indulhat el, hogy az orvosi rehabilitáció irányát kijelölik. A rehabilitáció első főiránya a rehabilitációra szoruló személy alkalmassá tétele a jelenlegi, illetve az egészségkárosodása előtti vagy a meglévő képzettségének megfelelő munkakörben történó foglalkoztatásra, ideértve a munkakör és a munkafeltételek megfelelő átalakítását is. Ezért a véleményezőbizottságok elsőnek ennek lehetőségét vizsgálják. A foglalkozási rehabilitáció második főiránya az átképzés vagy betanítás olyan új szakmára, amelyben az illető az egészségkárosodása jellegéből következően alkalmas vagy alkalmassá tehető a foglalkoztatásra. Megállapítható, hogy a komplex rehabilitáció előkérdése valójában az egészségi állapotban a jövőre nézve várható pozitív változás, amely az orvosi rehabilitációval érhető el. Minden további elem erre épül, azaz a rendszer kulcskérdése az orvosi rehabilitáció fejlesztése. A hazai rehabilitációs rendszer pénzbeli és természetbeni ellátásai külön-külön is sokelemúek, és azok gyakran nem épülnek egymásra, összehangolásuk problematikus. A komplex rehabilitáció fejlesztésében rejlő eredményeken túl érdemes figyelmet fordítani a statisztikai adatokból nyerhető tendenciára is. A 2001 és 2011 között eltelt tíz év alatt ugyanis 10\%-kal növekedett a nők aránya az aktív korúak által igényelt rokkantsági ellátásoknál. A területi eloszlást tekintve Vas,
Zala, Tolna és Győr-Moson-Sopron megyében még akkor is növekedés volt megfigyelhető a korhatár alatti rokkantsági nyugdíjasok számában (2. ábra), amikor az ország többi területén csökkenés volt tapasztalható [18]. Különösen érdekes ez az adat akkor, ha összevetjük a rokkantság alapjául szolgáló kórállapotokkal, illetve azok területi előfordulási gyakoriságával. A statisztikai adatsorok alapján a rokkantság alapjául szolgáló betegségek elsôsorban a daganatos betegségek, a vérkeringési rendszer betegségei, valamint a mentális és pszichiátriai megbetegedések. Ezen betegségcsoportok geográfiai gyakorisági eloszlását vizsgálva nem található szoros egyezés az említett négy megye magas rokkantsági arányával.

\section{Megbeszélés}

A megváltozott munkaképességű személyek pénzbeli ellátása az E. Alap rendkívül nagy hányadát alkotja. A kiadások redukálására, illetve a rokkantsági ellátásban részesülők számának csökkentésére az elmúlt másfél évtizedben komoly és komplex intézkedéseket tettek. Ez a jogalkotásban, az egészségkárosodás véleményezésére hivatott intézményhálózat többszöri átalakításában, valamint a munkaképesség-csökkenés, illetve az egészségkárosodás értékelési szempontrendszerének ismételt átfogó revíziójában is megmutatkozott.

Ugyanakkor hangsúlyozni szükséges, hogy a modern orvoslásban a korszerű rehabilitációs ellátások meghatározó szerepet vállalhatnak a megváltozott munkaképességű személyek munkaképességének javításában, helyreállításában [31, 36, 37].

A rokkantsági ellátások valós alternatíváját a komplex rehabilitációs járadék képezheti, ugyanakkor a komplex rehabilitáció eredménye - és így az egyén sikeres munkaerópiaci reintegrációja - kizárólag valamennyi intézményrendszer valós és összehangolt, együttes, jól koordinált együttmúködésével valósulhat meg. A rendszer bármely elemének csökkent vagy hibás múködése a teljes komplex rehabilitáció eredménytelenségének veszélyét hordozza, ez pedig azt jelenti, hogy az eredménytelen rehabilitációs időszakot követően a járadékos rokkantsági nyugdíj iránti igényt fog benyújtani, a rehabilitációra folyósított járadék pedig nem hasznosul sem az egyén, sem pedig a társadalom szempontjából.

A keresőképtelenséggel kapcsolatos betegségjellemzők, diagnózisok és elszámolási adatok országos gyưjtését az OEP már az 1990-es évek végén elkezdte szisztematikusan gyújteni [38]. Az átmeneti vagy tartós keresőképtelenség leggyakoribb okai között a mozgásszervi megbetegedések szerepelnek [39-45].

A korhatár előtti rokkantsági ellátásokra fordított kiadások csökkenése az orvosszakértői minősítési rendszer további átalakításától már nem várható, csak a komplex rehabilitáció intézményrendszerének fejlesztésétől, hatékonyabb múködésétől. 
Anyagi támogatás: A közlemény a Magyar Nemzeti Bank Pallas Athéné Innovációs és Geopolitikai Alapítványának (PAIGEO) pályázati támogatásával készült, „A pénzbeli és természetbeni ellátások arányai az Egészségbiztositási Alap költségvetésében a munkaeröpiaci folyamatok tükrében” címú 26/2017. (05. 12.) kuratóriumihatározat-számú projekt keretében.

A szerző a cikk végleges változatát elolvasta és jóváhagyta.

\section{Érdekeltségek: A szerzőnek nincsenek érdekeltségei.}

\section{Irodalom}

[1] Legislative Decree 40 of 1958 on the social security pension for workers. [1958. évi 40. törvényerejü rendelet a dolgozók társadalombiztosítási nyugdíjáról.] Hatályos jogszabályok gyújteménye, Wolters Kluwer, Budapest. [Hungarian]

[2] Andorka R, Tóth IGy. Social spending and social policy in Hungary. In: Andorka R, Kolosi T, Vukovich Gy. (eds.) Social report. [A szociális kiadások és a szociálpolitika Magyarországon. In: Andorka R, Kolosi T, Vukovich Gy. (szerk.) Társadalmi riport.] TÁRKI, Budapest, 1992; pp. 396-507. [Hungarian]

[3] Act II of 1975 on social security. [1975. évi II. törvény a társadalombiztosításról.] Hatályos jogszabályok gyűjteménye, Wolters Kluwer, Budapest. [Hungarian]

[4] Augusztinovics M, Gál RI, Matits Á, et al. The Hungarian pension system before and after the 1998 reform. [A magyar nyugdíjrendszer az 1998-as reform előtt és után.] Közgazdasági Szle. 2002; 49: 473-517

[5] Act XL of 1928 on compulsory insurance for old age, disability, widowhood and orphanage. [1928. évi XL. törvénycikk az öregség, rokkantság, özvegység és árvaság esetére szóló kötelező biztosításról.] Hatályos jogszabályok gyújteménye, Wolters Kluwer, Budapest. [Hungarian]

[6] Karsai L. (ed.) Statistical report, 1990. [Statisztikai jelentés, 1990.] Országos Társadalombiztosítási Fóigazgatóság, Budapest, 1991. [Hungarian]

[7] Ferge Zs. Social legislation since the change of regime. [Szociális törvénykezés a rendszerváltás óta.] Esély 1998; 3: 3-23. [Hungarian]

[8] Boncz I, Nagy J, Sebestyén A, et al. Financing of health care services in Hungary. Eur J Health Econ. 2004; 5: 252-258.

[9] Inotai A, Nguyen HT, Hidayat B, et al. Guidance toward the implementation of multicriteria decision analysis framework in developing countries. Expert Rev Pharmacoecon Outcomes Res. 2018; 18: 585-592.

[10] Boncz I, Kaló Z, Mohamed Ibrahim MIB, et al. Further steps in the development of pharmacoeconomics, outcomes research, and health technology assessment in Central and Eastern Europe, Western Asia, and Africa. Value Health Reg Issues 2013; 2: 169170 .

[11] Kiss G, Kovácsné VB, Tóth ÁL, et al. Efficiency examination of a 6-month trunk prevention program among recruitment kayakcanoe athletes: A randomized control trial. J Back Musculoskelet Rehabil. 2018 Nov 16. doi: 10.3233/BMR-181297. [Epub ahead of print]

[12] Boncz I, Dózsa C, Kaló Z, et al. Development of health economics in Hungary between 1990-2006. Eur J Health Econ. 2006; 7(Suppl 1): S4-S6.

[13] Boncz I, Sebestyén A. Financial deficits in the health services of the UK and Hungary. Lancet 2006; 368: 917-918.

[14] Boncz I, Evetovits T, Dózsa Cs, et al. The Hungarian Care Managing Organization Pilot Program. Value Health Reg Issues $2015 ; 7: 27-33$
[15] Endrei D, Molics B, Ágoston I. Multicriteria decision analysis in the reimbursement of new medical technologies: real-world experiences from Hungary. Value Health 2014; 17: 487-489.

[16] Csanádi $\mathrm{M}$, Löblová $\mathrm{O}$, Ozierański $\mathrm{P}$, et al. When health technology assessment is confidential and experts have no power: the case of Hungary. Health Econ Policy Law 2018 Mar 26. doi: $10.1017 /$ S1744133118000051. [Epub ahead of print]

[17] Greenberg D, Mohamed Ibrahim MIB, Boncz I. What are the challenges in conducting cost-of-illness studies? Value Health Reg Issues 2014; 4: 115-116.

[18] Boncz I, Nagy J, Körösi L, et al. The effect of the introduction of visit fee on the number of patient-visits to outpatient care departments in Hungary. Value Health 2008; 11: A368-A369.

[19] Main characteristics of under-age disability pensioners 20012011. [A korhatár alatti rokkantsági nyugdíjasok főbb jellemzői 2001-2011.] Központi Statisztikai Hivatal, Budapest, 2013. július. [Hungarian]

[20] Bancsi ZsJ. Rules of disabled being in Hungary. [A rokkant lét szabályai Magyarországon.] Debreceni Jogi Múhely 2010; 7(1): 47-67. [Hungarian]

[21] Ministry of Human Resources, Department of National Health Insurance Fund Management. Payment of the Health Insurance Fund's 2016 budget. [Az Egészségbiztosítási Alap 2016. évi költségvetésének pénzforgalmi teljesítése.] Országos Egészségbiztosítási Pénztár, Költségvetési és Gazdálkodási Főosztály, Budapest, 2016. [Hungarian]

[22] Boncz I, Vajda R, Agoston I, et al. Changes in the health status of the population of Central and Eastern European countries between 1990 and 2010. Eur J Health Econ. 2014; 15(S1): 137141.

[23] Endrei D, Zemplényi A, Molics B, et al. The effect of performance-volume limit on the DRG based acute care hospital financing in Hungary. Health Policy 2014; 115: 152-156.

[24] Boncz I, Sebestyen A, Pinter I, et al. Age group-specific gap between treatment cost of and mortality due to breast and colorectal cancer. J Clin Oncol. 2007; 25: 4501-4502.

[25] Boncz I, Sebestyen A, Dobrossy L, et al. The role of immunochemical testing for colorectal cancer. Lancet Oncol. 2006; 7 : 363-364.

[26] Péter I, Jagicza A, Ajtay Z, et al. Balneotherapy in psoriasis rehabilitation. In Vivo 2017; 31: 1163-1168.

[27] 7/2012. (II. 14.) NEFMI decree on detailed rules for the certification of the complex classification of disabled persons. [7/2012 (II. 14.) NEFMI rendelet a komplex minősítésre vonatkozó részletes szabályokról.] Hatályos jogszabályok gyújteménye, Wolters Kluwer, Budapest. [Hungarian]

[28] Act LXXXIV of 2007 on rehabilitation allowance, $\$$ 1. [2007. évi LXXXIV. törvény a rehabilitációs járadékról, 1. \$.] Hatályos jogszabályok gyújteménye, Wolters Kluwer, Budapest. [Hungarian]

[29] Tóth L, Lápossy A. Report of the Commissioner for Fundamental Rights in the case of AJB-760/2016. Related Matters: AJB775/2016, AJB-777/2016. [Az alapvető jogok biztosának Jelentése az AJB-760/2016. számú ügyben. Kapcsolódó ügyek: AJB-775/2016, AJB-777/2016.] Budapest, 2016. március. [Hungarian]

[30] State Audit Office in Hungary: Pulay Gy. (ed.) Support system for people with altered working ability and their socio-economic efficiency. [Az Állami Számvevőszék Kutató Intézete: Pulay Gy. (szerk.) A megváltozott munkaképességű személyek támogatási rendszere, társadalmi-gazdaságossági hatékonyságának vizsgálata.] Budapest, 2009. október. [Hungarian]

[31] Sallai JR, Hunka A, Héjj G, et al. Helping reintegration of patients suffering from chronic musculoskeletal diseases with decreased working ability in the National Institute of Rheumatology and Physiotherapy, Budapest, Hungary. [Csökkent munkaképességû́ krónikus mozgásszervi betegek reintegrációjának elősegítése.] Orv Hetil. 2017; 158: 662-667. [Hungarian] 
[32] Illés ST. Low back pain: when and what to do? [A derékfájás: mit és mikor tegyünk?] Orv Hetil. 2015; 156: 1315-1320. [Hungarian]

[33] Horvath J. The role of the Medical Scientific Council's Forensic Committee in the consent judgments regarding private insurance companies. [Az Egészségügyi Tudományos Tanács Igazságügyi Bizottságának szerepe a magánbiztosító társaságokat érintő jogerős ítéletekben.] Orv Hetil. 2008; 149: 1457-1462. [Hungarian]

[34] Hegedűs B, Varga J, Somfay A. Interdisciplinary rehabilitation in patients with ankylosing spondylitis. [Az interdiszciplináris rehabilitáció hatása spondylitis ankylopoeticában szenvedő betegekben.] Orv Hetil. 2016; 157: 1126-1132. [Hungarian]

[35] Müller A, Balatoni I, Csernoch L, et al. Quality of life of asthmatic patients after complex rehabilitation treatment. [Asztmás betegek életminőségének változása komplex rehabilitációs kezelés után.] Orv Hetil. 2018; 159: 1103-1112. [Hungarian]

[36] Apor P. Cardiac rehabilitation and its sporty face. [A szívbetegek rehabilitációjának sportos arca.] Orv Hetil. 2018; 159: 13461352. [Hungarian]

[37] Poór AK, Sárdy M, Cserni T, et al. Assessment of health-related quality of life in psoriasis patients in Hungary. [Psoriasisban szenvedő betegek életminőségének vizsgálata Magyarországon.] Orv Hetil. 2018; 159: 837-846. [Hungarian]

[38] Boncz I, Flamis L, Győrvári S. ICD based data collection of sickpay data in County Vas. [BNO alapú keresőképtelenségi adatgyúijtés tapasztalatai Vas megyében.] Lege Artis Med. 2002; 12: 315-320. [Hungarian]

[39] Juhász K, Boncz I, Patczai B, et al. Risk factors for contralateral hip fractures following femoral neck fractures in elderly: analysis of the Hungarian nationwide health insurance database. Eklem Hastalik Cerrahisi 2016; 27: 146-52.
[40] Molics B, Hanzel A, Nyárády J, et al. Utilization indicators of physiotherapy in musculoskeletal and connective tissue disorders for outpatient care. [Fizioterápiás járóbetegellátás igénybevételi mutatói a mozgásszervi kórképek kezelésében.] Magyar Traumatológia Ortopédia Kézsebészet Plasztikai Sebészet 2013; 56: 305-315. [Hungarian]

[41] Juhász K, Boncz I, Kanizsai P, et al. Analysis of the prognostic factors influencing the time elapsing until the contralateral hip fracture. [Az ellenoldali csípótáji törésig eltelt időt befolyásoló prognosztikai tényező́k vizsgálata.] Orv Hetil. 2018; 159: 15431547. [Hungarian]

[42] Járomi M, Kukla A, Szilágyi B, et al. Back School programme for nurses has reduced low back pain levels: a randomised controlled trial. J Clin Nurs. 2018; 27: e895-e902.

[43] Molics B, Kránicz J, Schmidt B, et al. Utilization of physiotherapy services for traumatic disorders of the lower extremity in ambulatory care. [A fizioterápiás jellegü tevékenységek igénybevételi mutatói a járóbeteg-szakellátásban az alsó végtag traumatológiai kórképei esetében.] Orv Hetil. 2013; 154: 985992. [Hungarian]

[44] Bergier B, Bergier J, Niźnikowska E, et al. Differences in physical activity and nutrition- and silhouette-related behaviours in male and female students in selected European countries. Ann Agric Environ Med. 2018; 25: 176-181.

[45] Molics B, Boncz I, Leidecker E, et al. Health insurance aspects of physiotherapeutic care of neurology disorders in outpatient care. [A neurológiai kórképek fizioterápiás ellátásának egészségbiztosítási vonatkozásai a járóbeteg szakellátásban.] Ideggyogy Sz. 2015; 68: 399-408. [Hungarian]

(Kovács Gábor dr., Gyôr, Szent Imre út 26-28., 9024 e-mail: gkovacs@sze.hu)

A cikk a Creative Commons Attribution-NonCommercial 4.0 International License (https://creativecommons.org/licenses/by-nc/4.0) feltételei szerint publikált Open Access közlemény, melynek szellemében a cikk nem kereskedelmi célból bármilyen médiumban szabadon felhasználható, megosztható és újraközölhető, feltéve, hogy az eredeti szerző és a közlés helye, illetve a CC License linkje és az esetlegesen végrehajtott módositások feltüntetésre kerülnek. 